\title{
Integrated Assessment of Natural Hazards, Including Climate Change's Influences, for Cultural Heritage Sites: The Case of the Historic Centre of Rethymno in Greece
}

\author{
Mohammad Ravankhah ${ }^{1} \cdot$ Rosmarie de $\mathrm{Wit}^{2} \cdot$ Athanasios V. Argyriou ${ }^{3} \cdot$

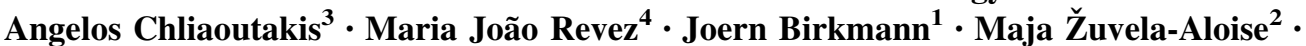 \\ Apostolos Sarris $^{3,5} \cdot$ Anastasia Tzigounaki $^{6} \cdot$ Kostas Giapitsoglou $^{6}$
}

Published online: 19 September 2019

(C) The Author(s) 2019

\begin{abstract}
Within the framework of disaster risk management, this article proposes an interdisciplinary method for the analysis of multiple natural hazards, including climate change's influences, in the context of cultural heritage. A taxonomy of natural hazards applicable to cultural heritage was developed based on the existing theoretical and conceptual frameworks. Sudden-onset hazards, such as earthquakes and floods, and slow-onset hazards, such as wetting-drying cycles and biological contamination, were incorporated into the hazard assessment procedure. Future alteration of conditions due to climate change, such as change in heat waves' duration, was also taken into account. The proposed hazard assessment framework was applied to the case of the Historic Centre of Rethymno, a city on the northern coast of the island of Crete in Greece,
\end{abstract}

Mohammad Ravankhah

mohammad.ravankhah@ireus.uni-stuttgart.de;

mravan60@gmail.com

1 Institute of Spatial and Regional Planning (IREUS - Institut für Raumordnung und Entwicklungsplanung), University of Stuttgart, 70174 Stuttgart, Germany

2 Central Institution for Meteorology and Geodynamics (ZAMG - Zentralanstalt für Meteorologie und Geodynamik), 1190 Vienna, Austria

3 GeoSat ReSeArch Lab, IMS-FORTH (Geophysical-Satellite Remote Sensing and Archaeoenvironment Lab, Institute for Mediterranean Studies-Foundation for Research and Technology, Hellas), 74100 Rethymno, Greece

4 Nova Conservação, S.A., 1200-872 Lisbon, Portugal

5 The Archaeological Research Unit, Department of History and Archaeology, University of Cyprus, 1678 Nicosia, Cyprus

6 Ephorate of Antiquities of Rethymno, 74100 Rethymno, Greece to identify, analyze, and prioritize the hazards that have the potential to cause damage to the center's historic structures. The assessment procedure includes climate model projections, GIS spatial modeling and mapping, and finally a hazard analysis matrix to enable the sharing of a better understanding of multiple hazards with the stakeholders. The results can facilitate decision making by providing the vulnerability and risk analysis with the nature and spatial distribution of the significant hazards within the study area and its setting.

Keywords Climate change analysis $\cdot$ Crete $\cdot$ Cultural heritage protection - Greece $\cdot$ Hazard assessment · Historic centre of Rethymno - Risk assessment

\section{Introduction}

In order to build the conceptual and methodological frameworks of this interdisciplinary study, the link between natural hazards and disasters as well as the development of risk management in the context of heritage conservation need to be elaborated.

\subsection{Natural Hazards and Disasters}

Natural hazards can be defined as phenomena associated with geophysical processes in the environment that embody the potential for damage or loss that exists in the presence of a vulnerable human community (Stillwell 1992). The definition emphasizes the link between natural and social systems in framing potential damage. Bokwa (2013, p. 715) indicates that "over time, attribution of natural hazards and disasters has been shifted from 
supernatural or mystical forces, to nature (physical forces in natural systems), and with some reluctance, to humans who have made changes to natural systems." Kelman (2018) categorizes hazards into entirely from nature (for example, a meteorite), entirely from human activity (for example, pollution), or a combination of the two (for example, flood depth and speed augmented by channeling rivers).

When it comes to the classification of natural hazards and disasters to distinguish one class of phenomena from others, Glade and Alexander (2013) indicate speed of onset and duration as the significant criteria in classifying events-drought and soil erosion, for example, are slowonset events. A similar approach has been applied by Smith and Petley (2009) to the classification of environmental hazards into rapid-onset and slow-onset; however, they concentrate mainly on the first category that may directly threaten human communities by means of acute physical or chemical trauma on a scale sufficient to cause a disaster. Although the terms "hazard" and "disaster" might be differently defined in the natural, social, and applied sciences, distinguishing the two terms is key in the risk assessment and management frameworks. Kelman (2018) - highlighting the role of long-term human values, decisions, and activities in the vulnerability contexts that give rise to disasters-emphasizes that "a hazard might be rapid-onset, but the disaster, requiring much more than a hazard, is a long-term process, not a one-off event, so a disaster cannot be rapid-onset" (Kelman 2018, p. 288). In other words, if mitigation (including technical, social, and logistic aspects) is considered in advance, fast-onset events may not cause a sudden and unexpected crisis, and slowonset events (for example, droughts) may be predicted and mitigated before they turn to disasters (Menoni and Pugliano 2013).

Recognizing the disaster complexity paradigm, Smith and Petley (2009, p. 8) approach hazards and disasters as two sides of the same coin-neither can be entirely understood or clarified from the standpoint of either physical science or social science alone. To address the role of physical (or, better called, socio-physical) hazard and social (or, better called, socio-physical) vulnerability in emerging disasters, integrated approaches are needed in risk assessment and management (Wisner et al. 2004; Birkmann 2006; Smith and Petley 2009; Gaillard and Kelman 2013; Stewart 2013). Such integrated approaches need to be considered within each community or discipline dealing with disaster and risk, as well as in an interdisciplinary way between them.

While the integration of disaster risk management and climate change adaptation was emphasized in the Intergovernmental Panel on Climate Change report (IPCC 2012) on Managing the Risks of Extreme Events and
Disasters to Advance Climate Change Adaptation, disciplinary boundaries with respect to, for example, terminological and methodological approaches make it difficult to implement such an integration in hazard and risk assessment. This article explores potential natural hazards (including climate change impacts) in the context of cultural heritage and proposes a framework for assessing multiple hazards within the overall risk assessment procedure.

\subsection{Cultural Heritage and Natural Hazards}

Cultural heritage properties as an integral part of the built environment play a significant role in economic development and in strengthening social capital and cultural diversity. The 2030 Agenda for Sustainable Development (UN 2015, p. 18) Goal 11-Make cities and human settlements inclusive, safe, resilient and sustainable-explicitly acknowledges "heritage" in its target 11.4: "strengthen efforts to protect and safeguard the world's cultural and natural heritage." Subsequently, the incorporation of cultural heritage in disaster resilience was highlighted in the Sendai Framework for Disaster Risk Reduction 2015-2030 (UNISDR 2015b). Historic sites are extremely exposed to the adverse effects of natural hazards, with consequences ranging from gradual decay and deterioration to outright catastrophic losses. The increased frequency and intensity of extreme weather events as a result of climate change have made the situation even worse, calling for integrated methodologies and processes for risk assessment and management that are applicable to heritage conservation.

A recent report for the Europe region from UNESCO's World Heritage Centre (2015) remarked that natural hazards, and particularly climate change-related factors, ranked high in site managers' concerns regarding the state of conservation of World Heritage properties: "In particular, the lack of preparedness to address threats related to climate change as well as risk management, in general, were mentioned frequently in the chapter on capacity building needs" (UNESCO World Heritage Centre 2015, p. 65); these results plausibly reflect the context of most European heritage sites.

Natural hazards that affect cultural heritage may vary greatly in terms of aggressiveness: saline spray or pollution, for example, will have a slow and persistent effect on a heritage object, whereas a flood or a wildfire is likely to have a much more drastic impact, although this kind of event occurs more sporadically. The nature of the inflicted damage will also vary: sudden-onset events typically cause significant impacts at a structural level (macro scale), although sequels may be left behind acting at a microscale; whereas slow-onset phenomena will primarily cause stresses at material level (meso-micro scale), even if these are bound to eventually lead to structural collapse if 
nothing is done to prevent it. In other words, while both types of natural hazards have negative impacts on heritage assets, the pathways and corresponding time frames for a disastrous situation to occur are quite different and strongly influence the required conservation planning. Although "according to the mathematical definition of risk, multiple small losses represent the same risk as a rarely occurring major event" (Ammann 2006, p. 5), there is a general tendency for the public and decision makers to perceive major events as more serious; thus, risk aversion also plays a role when hazards are being assessed.

(Heritage) Conservation may be defined as "All actions designed to understand a heritage property or element, know, reflect upon and communicate its history and meaning, facilitate its safeguard, and manage change in ways that will best sustain its heritage values for present and future generations" (Nara+20 2016, p. 147). Conservation, in this sense, encompasses a vast array of actions and procedures, including all those directed at the sustainable management of change to a significant place. Disaster risk management (DRM), it is argued, may serve as a conceptual tool that allows for an integrated management of change to heritage assets, that is, for a more holistic conservation process (Revez et al. 2016), one that addresses both slow-acting and sudden-acting hazards and threats.

Recognizing the above challenges, the STORM (Safeguarding Cultural Heritage through Technical and Organisational Resources Management) project (STORM 2016-2019) developed an innovative methodology and associated supporting tools and services to assess and manage risks associated with natural hazards. The methodology was tested in five pilot sites in Greece, Italy, Portugal, Turkey, and the United Kingdom. Even though some valuable efforts have been devoted to a risk assessment methodology for cultural heritage (FEMA 2005; D'Ayala et al. 2008; UNESCO World Heritage Centre et al. 2010), an integrated approach to the assessment of natural hazards while considering climate change influences still needs further development. Within the scope of the STORM project, this article presents an integrated methodology for the identification, analysis, and prioritization of natural hazards (including climate change influences), applied to five significant historic sites in the Historic Centre of Rethymno on the island of Crete in Greece. The hazard assessment procedure will further support the overall risk assessment and management framework in the STORM project.

\section{Methodological Framework}

Risk reduction relies on addressing a wide range of past and future hazards, as well as the socio-physical features of the vulnerable elements exposed to those hazards. Hazard assessment is an integral part of the risk assessment procedure in determining the nature and level of risk. Methods and tools to apply to the hazard assessment and mapping may vary depending on the objectives and scope of the assessment, disciplinary background, nature of the hazards or multiple hazards, and data availability and accessibility. Zschau (2017) recognizes three hazard analysis methods: hazard matrices, by applying a color code for hazard classification; hazard indices, by applying aggregation of indicators; and hazard curves, presenting exceedance probabilities for a certain hazard's intensities in a specific period. Simmons et al. (2017) indicate that overall assessment approaches can be based on subjective scenario-based deterministic models, semiquantitative risk analyses such as risk matrices, or fully quantitative risk assessments such as probabilistic or stochastic risk modeling. The SEERISK project "Joint Disaster Management Risk Assessment and Preparedness in the Danube MacroRegion" (SEERISK 2014), for instance, developed multiple alternatives for qualitative and quantitative hazard assessment and mapping. In this project, a qualitative hazard assessment can be conducted based on historical data or expert judgement, while in the quantitative hazard analysis "a hazard map may be deterministic (showing the distribution of the intensity of a specific hazard scenario) or probabilistic (showing the distribution of the probability of occurrence in the study area)" (SEERISK 2014, p. 24).

One of the main challenges in the STORM project was the large number of environmental hazards (sudden- and slow-onset) that may likely affect the project pilot sites. Thus, the assessment and prioritization of hazards and threats played a key role in framing the initial steps of the risk assessment. To determine the nature and extent of risk, risk assessment needs to understand the characteristics of potential hazards (for example, severity and likelihood), as well as the characteristics of the elements at risk (for example, physical and social). For cultural heritage sites exposed to a wide range of hazards, assessment and prioritization of the hazards that need to be incorporated into the further risk assessment steps, including vulnerability assessment, is of paramount importance. Vulnerability analysis of historic sites is a very complex and resourceconsuming procedure; furthermore, the susceptibility analysis of historic structures to different hazards might need quite different methodologies and techniques. Thus, the identification of hazards of interest is critical to ensure that the risk assessment/management will lead to the site- 
and hazard-specific strategies practical for the protection of sites from sudden- and slow-onset hazards. Accordingly, the proposed hazard assessment procedure of the project was developed in such a way as to achieve three objectives:

- Identification of natural hazards, including climate change influences, likely to affect a study area;

- Analysis of the natural hazards and threats through quantifying their severity, likelihood, and future changes; and

- Evaluation of the natural hazards and threats to determine those that need to be integrated into the further risk assessment procedure and conservation strategies.

\subsection{Classification of Natural Hazards}

To establish the context, a taxonomy of natural hazards was developed based on the existing literature, projects, and international frameworks in the area of disaster management (FEMA 2012; UNISDR 2015a), climate change adaptation (Drdácký and Chapuis 2007; Füssel 2012), and heritage conservation (Camuffo 1997; Colette 2007). Particular hazards and threats that may affect cultural heritage sites were identified and incorporated into the hazard inventory. Applicability of the hazard inventory to the field of heritage conservation and the specific requirements of the pilot sites were particularly taken into account. Natural hazards and threats are categorized into geological, hydrometeorological, and biological hazards (Fig. 1). Most of these hazards and threats can be called "socio-natural hazards" (UNISDR 2015a), since they can be the result of both natural and anthropogenic factors. Landslides, acid rain, and riverside erosion, for example, may be caused by a combination of environmental factors (for example, rainfall) and human activities (for example, land-use change and pollution). However, we are using the term "natural hazards" in this article to distinguish these hazards from purely anthropogenic hazards. Although anthropogenic hazards (for example, technological hazards, social conflict, and development pressure) are mentioned in the theoretical framework (Fig. 1), they were not included in the assessment procedure because they were beyond the scope of the STORM project.

To adequately address the short- and long-term effects of natural hazards and threats on heritage sites, the hazards are further categorized according to the speed of onset. Accordingly, sudden-onset hazards (for example, earthquakes, storms, and floods) and slow-onset hazards (for example, wetting-drying cycles and wind-driven rain) were incorporated into the hazard assessment procedure. Future alterations due to climate change, such as projected changes in hydrometeorological hazards (for example, precipitation intensity and heat waves), were also addressed in the assessment procedure.

Table 1 shows the proposed taxonomy of natural hazards, including climate change influences, that may potentially cause damage to cultural heritage properties.

Based on Table 1, a preliminary hazard profile was prepared for the Rethymno study area by gathering basic data regarding the historical frequency and severity of the hazards, as well as information about the historical impacts of the hazards on the study area. In the beginning of the project in 2016, an expert questionnaire with the site

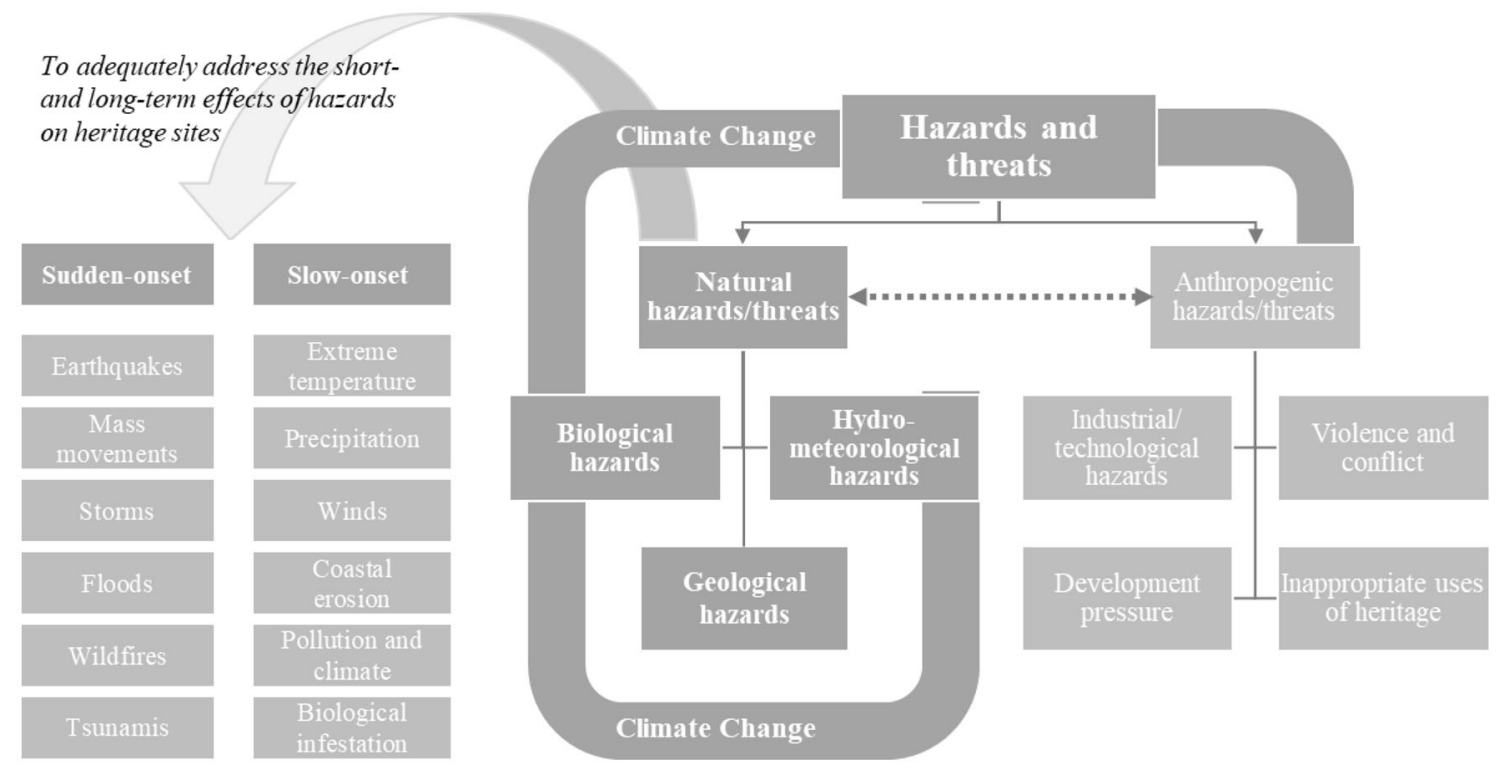

Fig. 1 Classification of natural (or socio-natural) hazards that may affect cultural heritage 
Table 1 Taxonomy of natural hazards (including climate change influences) that may affect cultural heritage. Sources The inventory of the hazards and threats was adapted from: UNDP/UNDRO (1992); Camuffo (1997); Colette (2007); Drdácký and Chapuis (2007); Below et al. (2009); Sabbioni et al. (2009); Smith and Petley (2009); UNESCO World Heritage Centre et al. (2010); Daly (2011); FEMA (2012); Füssel (2012); UNFCCC (2012); UNESCO World Heritage Centre (2014); UNISDR (2015a)

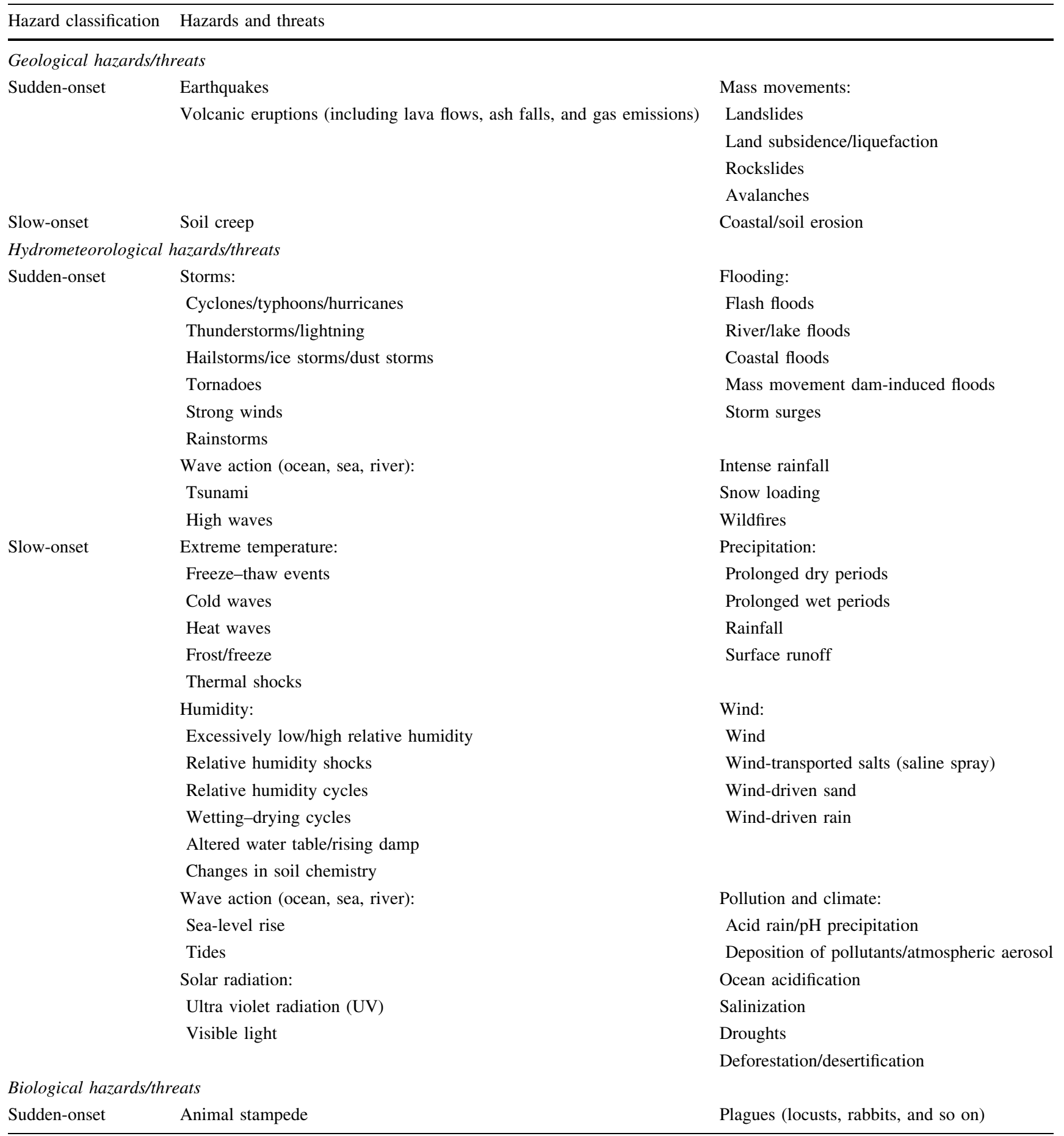


Table 1 continued

\begin{tabular}{lll}
\hline Hazard classification & Hazards and threats & \\
\hline Slow-onset & Biological colonization by fungi: & Biological colonization by plants: \\
& Lichen & Algae \\
& Moulds & Moss \\
& Mildew & Higher plants \\
& Dry or wet rot & Biological colonization by bacteria \\
& Biological colonization by animals (pests): & \\
& Insects (wasps, spiders, termites, woodworms, bookworms, and so on, including nests) \\
& Birds (pigeons, seagulls, and so on, including nests) & \\
& Mammals (mice, bats, rabbits, and so on including nests) &
\end{tabular}

managers and heritage experts in the Ephorate of Antiquities of Rethymno (EFARETH) as well as with the hazard modeling experts in the Foundation for Research and Technology, Hellas (FORTH) was conducted to provide a preliminary list of hazards and threats that needed to be analyzed further.

\subsection{Analyzing and Evaluating the Natural Hazards}

A semiquantitative analysis (adapted from HAZUS-MH, FEMA 2004) was applied to facilitate the overall hazard analysis procedure. Semiquantitative methods, which use numerical rating scales for consequence and probability, for example, allow multiple components and factors that may influence the level of hazard or risk to be incorporated into a numerical scoring system (ISO 31010) (ISO 2009). Semiquantitative methods have been increasingly applied in the area of natural hazards and risk management, such as in Realising European ReSILiencE for Critical INfraStructure project (RESILENS 2016), mainly because they offer flexibility in integrating different indicators. Qualitative significance levels were also incorporated into the analysis procedure in the STORM project to promote the clarity of the process, the simplicity of the interpretation, and the practicality of the results for site managers and policymakers. Simmons et al. (2017, p. 55) point out that "the more qualitative approaches to risk add value through the process of developing a framework to capture subjective risk perception and serve as a starting point for a discussion about assumptions and risk recognition engaging a wide variety of experts and stakeholders in the process." Figure 2 shows the overall hazard assessment procedure in which four criteria of severity, likelihood, relevance of hazards for site managers, and expected intensity of impact were incorporated into the hazard analysis. The methodology employed a 1-5 rating scale based on which of the four criteria may fall into one of the five levels of Very low (1), Low (2), Medium (3), High (4), and Very High (5). Below, the four criteria in the hazard analysis procedure are defined.

\subsubsection{Severity of Natural Hazards and Threats}

A series of natural hazards was mapped through the employment of spatial modeling in the GIS environment, related to the main threats identified for the Historic Centre of Rethymno (HCR). The main input geospatial datasets acknowledged for the diverse hazard assessment mappings consist of: (1) a $12 \mathrm{~m}$ spatial resolution digital elevation model (DEM), acquired by the TanDEM-X satellite mission; (2) an archived dataset of past seismic activity epicenters, from the year 1900 to the year 2006, for the wider region of Rethymno, Crete, as compiled by the databases of the National Observatory of Athens and the Aristotle University of Thessaloniki catalogues; (3) geological and hydrolithological maps provided by the Institute of Geological and Mineral Exploration (IGME) and further processed by the laboratory of Geophysical-Satellite Remote Sensing and Archaeoenvironment (GeoSat ReSeArch) of the Foundation for Research and Technology, Hellas (FORTH). All spatial datasets were geo-referenced into a common geodetic system (EPSG: 4326, WGS 1984). The hazard modeling and mapping process is based on the availability of spatial data related to a particular hazard. Moreover, it is essential to acknowledge factors (available or derived spatial datasets) associated with the respective hazard as well as the appropriate spatial analysis tools. Different kinds of hazard models can be formulated by incorporating hazard-related factors (parameters) into the spatial analysis tools in order to provide effective hazard assessment results for the study area.

When it comes to changes in climate, although an increase in mean temperatures is among the most widely known effects, climate change can manifest itself in a variety of ways. For example, changes in the frequency or duration of heat waves may occur, intense precipitation 


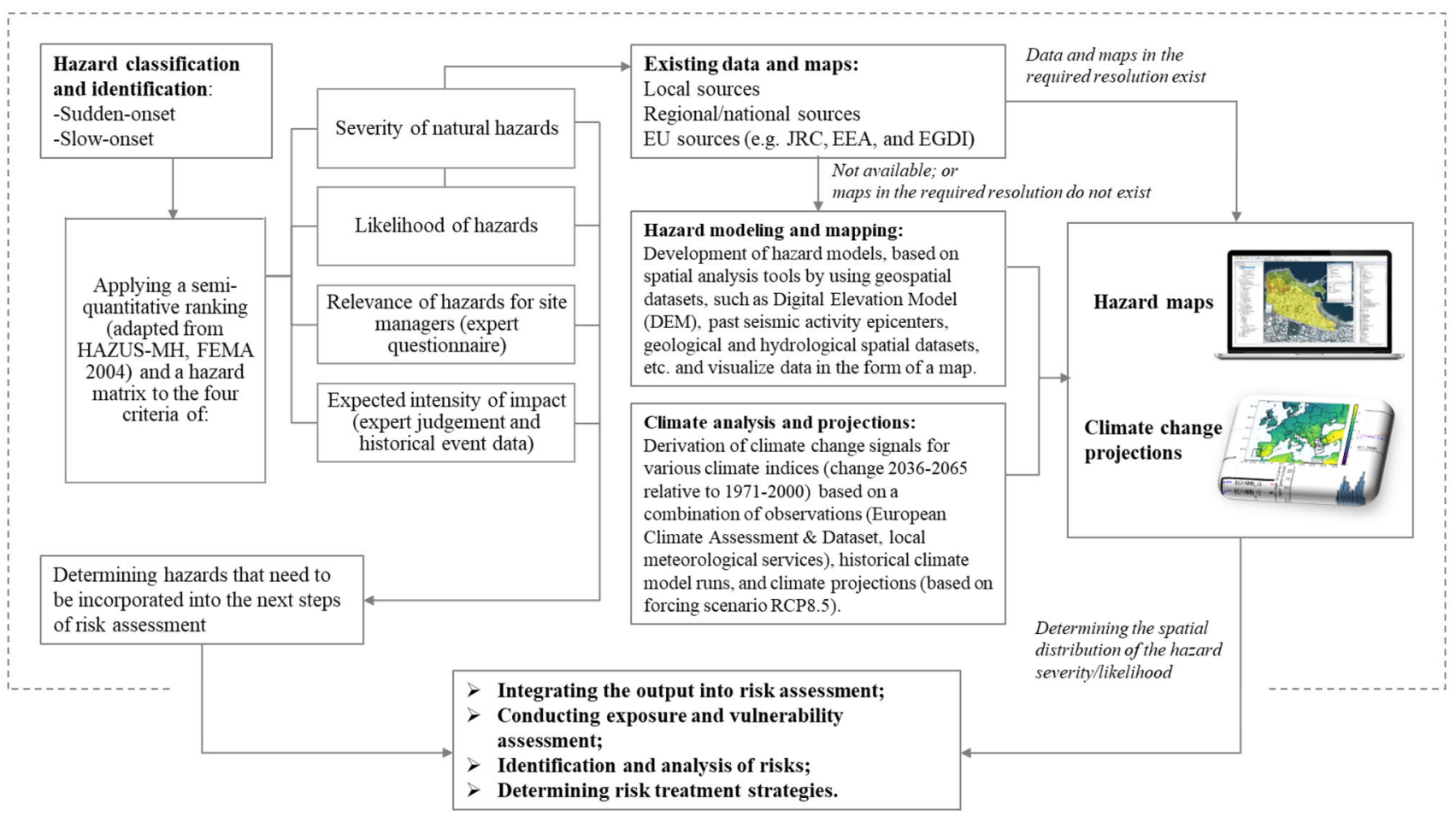

Fig. 2 Assessing natural hazards, including climate change projections, within the risk assessment procedure for the Historic Centre of Rethymno, Crete, Greece EU $=$ European Union; JRC $=$ Joint

could become more frequent, or the intensity of such events might increase. In order to capture the full range of effects of climate change on natural hazards, within the STORM project a set of standardized climate change indices as developed by the Expert Team on Climate Change Detection and Indices (ETCCDI) are considered (Sillmann et al. 2013). These indices are then assigned to the relevant STORM hazards, allowing for the assessment of the effects of climate change on these hazards. To quantify climate change effects, a comparison between the current climatic conditions and the projected future climate is performed. To this end, the local climate baseline was established for the Rethymno study area, taking the 30-year period 1971-2000 as a reference, using observations from monitoring stations in the vicinity of the study site. These measurements were either obtained through the European Climate Assessment \& Dataset (ECAD) network (Klok and Klein Tank 2009) or from the local weather services directly. Information about future conditions was acquired based on climate model projections, taking the 2036-2065 period as a base to be able to estimate the climate signal towards the middle of the century.
Research Centre (European Commission); EEA = European Economic Area; EGDI = United Nations E-Government Development Index

\subsubsection{Likelihood of Natural Hazards}

"Likelihood is based on probability and can be expressed in various ways, such as recurrence intervals, exceedance probabilities, return periods, probabilities or frequencies" (AEMC 2015, p. 38). The following likelihood table (Table 2) was adapted from AEMC (2015) to quantify the likelihood of sudden-onset hazards. Additional qualitative and quantitative scales were also developed for the slow-onset hazards associated with climate change (see Sect. 4.1). The level of likelihood may fall into Very rare (1), Rare (2), Possible (3), Likely (4), or Almost certain (5) (Table 2).

\subsubsection{Relevance of Natural Hazards for Site Managers}

This is an additional criterion to represent the relevance of hazards to a heritage site in the view of site managers and stakeholders. This criterion emphasizes the importance of stakeholders' perception at the local and site level, besides regional hazard data and maps. Relevance of hazards was incorporated into the assessment procedure through consultation with the site managers and heritage experts in the Ephorate of Antiquities of Rethymno (EFARETH) as well as the hazard modeling experts in the Foundation for Research and Technology, Hellas (FORTH). The level of 
Table 2 Natural hazard likelihood level. Source adapted from AEMC (2015)

\begin{tabular}{llll}
\hline Likelihood & Annual exceedance probability (AEP) & Frequency & Semiquantitative ranking in the STORM project \\
\hline Almost certain & $63 \%$ per year or more & Once or more per year & 5 \\
Likely & $10 \%$ to $<63 \%$ per year & Once per 10 years & 4 \\
Possible & $1 \%$ to $<10 \%$ per year & Once per 100 years & 3 \\
Rare & $0.1 \%$ to $<1 \%$ per year & Once per 1000 years & 2 \\
Very rare & $0.01 \%$ to $<0.1 \%$ per year & Once per 10,000 years & 1 \\
\hline
\end{tabular}

relevance of hazards to site managers may fall into Very low (1), Low (2), Medium (3), High (4), or Very high (5).

\subsubsection{Expected Intensity of Hazard Impact (a Preliminary Analysis)}

"Intensity is a measure of the effect of a hazard event at a particular place" (FEMA 2004, 2-2). The potential effect of hazards on the heritage assets of the study area, in this step, is a rapid estimation of impacts according to the existing data and expert opinions, in order to identify hazards of interest. In the further step of risk assessment, a detailed analysis of potential impacts needs to be conducted while looking at the vulnerability of heritage assets to the hazards of interest. The intensity of the potential impacts of the identified hazards in this step was addressed through a qualitative estimation of potential damages to the structural and nonstructural components that convey the heritage values of the site. The level of expected impact may fall into Insignificant (1), Minor (2), Moderate (3), Major (4), or Catastrophic (5) (Table 3).

Eventually, these ranking factors were incorporated into a hazard analysis matrix in order to determine the significance of each hazard. Following the hazard analysis, the hazards were evaluated by applying the ALARP (As Low As Reasonably Practicable) principle to determine those hazards that needed to be incorporated into the further steps of the risk assessment procedure.

\section{The Historic Centre of Rethymno and the Fortezza Fortress}

The coastal city of Rethymno is located in the middlewestern part of the island of Crete, on its north side (Fig. 3). It is one of the most important Cretan urban centers and a living heritage site due to the constant occupation of the area spanning from at least the Hellenistic period (323-67 BC) up to present. In 1212 the city was conquered by the Venetians and in 1646 by the Ottomans who remained in Crete until the beginning of the twentieth century. The diverse historical, architectural, and cultural values of the Historic Centre of Rethymno lead to its declaration as a monument in 1967. Today, the city has 35,000 inhabitants and the historical center has approximately 3000 inhabitants.

\subsection{Geological and Climatological Background}

Crete is a mountainous island, the largest of the Greek islands, located south of the Aegean Sea (Fig. 3). Its unique geographical position between Asia, Africa, and Europe determined its historical course, both throughout antiquity and in modern times. It has an elongated shape, having dimensions of $260 \mathrm{~km}$ along the east-west axis and a $60 \mathrm{~km}$ maximum width along the north-south direction. A number of tectonic basins and grabens formed two main mountain ranges, consisting of Lefka Ori and Psiloritis, with a maximum height of $2456 \mathrm{~m}$ above sea level (Sarris

Table 3 Expected intensity of hazard impact on historic masonry buildings (a preliminary analysis)

\begin{tabular}{|c|c|}
\hline $\begin{array}{l}\text { Intensity of } \\
\text { impact }\end{array}$ & Level of damage (masonry buildings) \\
\hline Catastrophic (5) & Serious destruction of structural and nonstructural elements or total collapse; highly significant loss in heritage values \\
\hline Major (4) & $\begin{array}{l}\text { Heavy structural damages (for example, large cracks in walls); failure of nonstructural elements (for example, fall of } \\
\text { decorative elements and collections); significant loss in heritage values }\end{array}$ \\
\hline Moderate (3) & Partial damages to structural elements (for example, cracks in walls) and nonstructural elements; partial loss in heritage values \\
\hline Minor (2) & $\begin{array}{l}\text { Minor damages to structural elements (for example, small cracks in few walls) and nonstructural elements; minor loss in } \\
\text { heritage values }\end{array}$ \\
\hline Insignificant (1) & Very minor damage to structural and nonstructural elements; negligible loss in heritage values \\
\hline
\end{tabular}


Fig. 3 Topographical map of Crete Island Rethymno District and its surroundings. The DEM (digital elevation model) indicates the variation of the terrain landforms expanding through the whole island. Four different categories of faults have been identified, two of which (active and potential active faults) have been correlated with the mainland seismic activity of the island. Source GeoSat ReSeArch Lab, IMS-FORTH

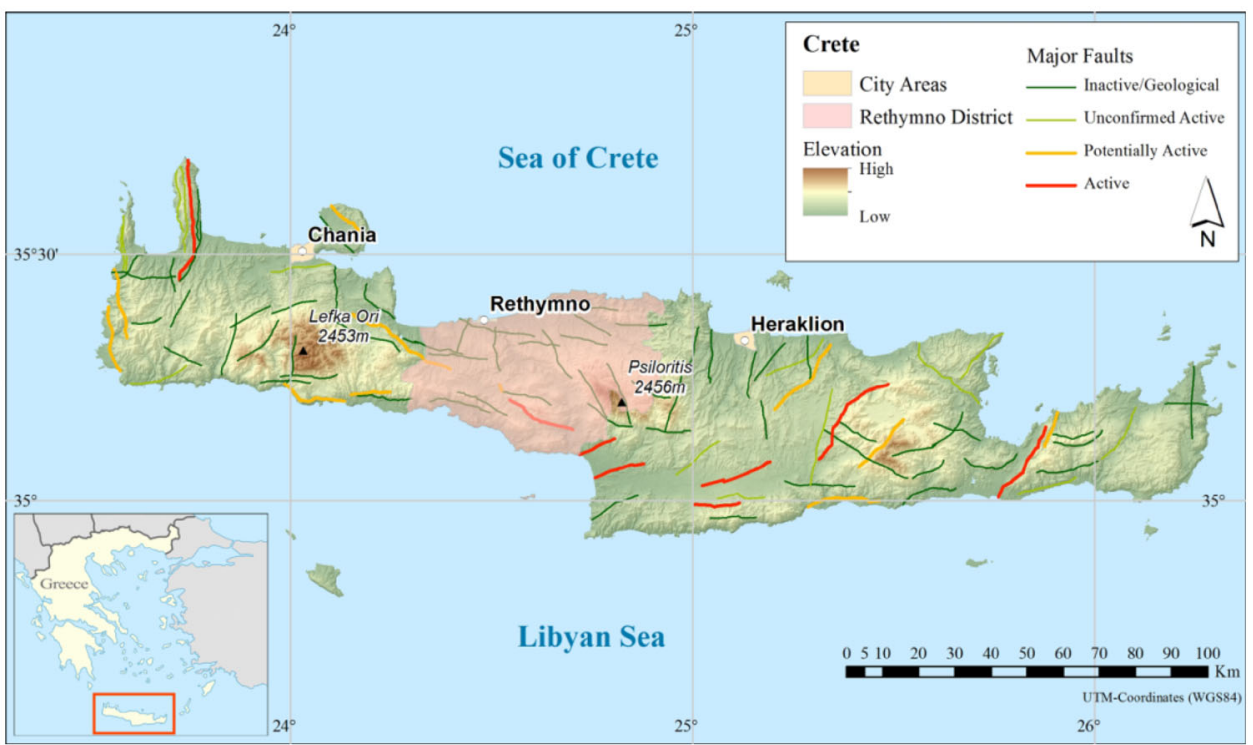

et al. 2005). The Rethymno District lies between these two largest mountainous blocks of the island. The region has a complex geomorphology with the presence of south-north directed gorges across the whole district. The largest ones are found in the southern part of the district such as Kourtaliotiko. There are also smaller gorges found in the surrounding landscape of the city of Rethymno that can be linked to tectonic activity and characterized by a rough terrain with steep slopes and ridges. In the northern part of the district, lower elevated areas (up to $\sim 800 \mathrm{~m}$ ) exist, with sandy beaches along the coastline. In contrast, its southern part is mainly characterized by higher elevations and rough terrain with rocky beaches along the coastline.

The climate of Rethymno District (based on observations at the Heraklion station, provided by ECAD - the European Climate Assessment and Dataset) is characterized by hot, dry summers and mild winters. During the 30-year average period 1971-2000, the average maximum summer temperatures were just under $28{ }^{\circ} \mathrm{C}$, and on the average 124 summer days were registered per year. Average minimum winter temperatures were $9.6{ }^{\circ} \mathrm{C}$, and no frost or ice days were observed. The average annual precipitation for the same period is $458 \mathrm{~mm}$, of which about half falls during the winter months and only about $5 \mathrm{~mm}$ in summer. On average, there are around 50 wet days per year: approximately 15 of these are heavy precipitation days, of which around 6 days are very heavy precipitation days (days with at least $10 \mathrm{~mm}$ or $20 \mathrm{~mm}$ precipitation per day, respectively).

\subsection{Cultural Heritage Properties in the Study Area}

In the STORM project, five heritage cases were chosen in the Historic Centre of Rethymno (HCR) for applying the hazard assessment methodology. The Fortezza Fortress (HCR-1) (Fig. 4) is the foremost landmark of the city of Rethymno and a fine specimen of Venetian defensive architecture. The architectural finds and buildings on the hill, where the Venetian fortress was built on, reflect the different functionalities they served as well as the changes subjected to during different historical phases.
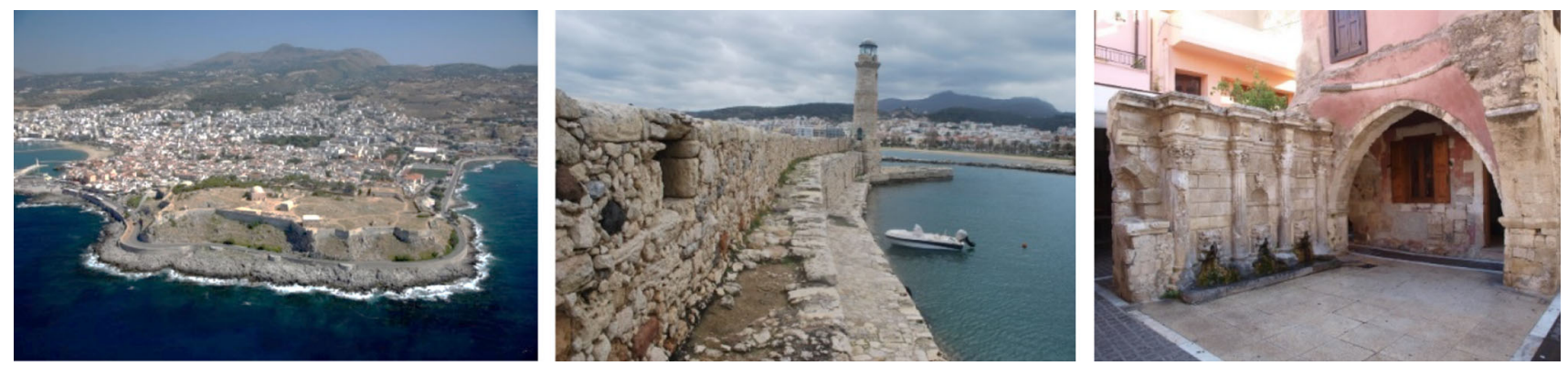

Fig. 4 Study sites in Rethymno, Crete, Greece. Left: Fortezza Fortress (c) Patroudakis Georgios, 2010; Middle: Lighthouse in the Venetian harbor (C) Ephorate of Antiquities of Rethymno archive, 2015; Right: Rimondi Fountain (c) Ephorate of Antiquities of Rethymno archive, 2016 
The fortress draws approximately 160,000 visitors per year, which makes it a source of social, cultural, and economic importance. The monument has evolved into one of the preferred locations for popular cultural events, reinforcing the cultural and social identity of the residents (Steriotou 1992). Within the Fortezza Fortress, there is a monument called the Episcopal Mansion (HCR-2). Its current poor preservation state prevents the full aesthetic appreciation of its original form. However, the arrangement of the architectural features in the interior of the monument is considered significant (Steriotou 1992).

In the urban area of Historical Centre of Rethymno, there is a Soap Factory (HCR-3) that constitutes a fine and unique example of the particular traditional craft. The Soap Factory is a very important monument of recent history and industrialization in Crete. Having been built in the second half of the nineteenth century, it constitutes the sole surviving remnant of the vibrant soap industry that developed and survived in Rethymno until the third quarter of the twentieth century. Although it is currently in a state of disrepair, potential restoration work would enable the reuse of the building (Paraskevas 2003). The Lighthouse in the Venetian harbor (HCR-4) (Fig. 4) is an example of the traditional lighthouse architecture and constitutes one of the two largest Egyptian lighthouses in Crete. Associated with the Egyptian rule in Crete, the Lighthouse is a significant landmark of that period and a popular subject of study by scholars of nineteenth century architecture ( $\mathrm{Pa}-$ padakis 2009). A unique example of Venetian fountain architecture in Rethymno is the Rimondi Fountain (HCR5) (Fig. 4). Its technology of water management represents an important achievement due to the $2 \mathrm{~km}$ long stone pipe that brought the water into the city. The fountain constitutes a major landmark for the inhabitants of the city and is a popular meeting place (Dimakopoulos 1970).

According to the preliminary hazard profile and expert questionnaire, the following hazards were identified as likely to threaten the Rethymno study area:

- Sudden-onset hazards: geological hazards (earthquakes, landslides, liquefaction, and rockslides), and hydrometeorological hazards (intense rainfall, strong winds, high waves, flash floods, coastal floods, snow loading, and tsunamis); and

- Slow-onset hazards: geological hazards (coastal erosion), hydrometeorological hazards (heat waves / cold waves, salinization, surface runoff, humidity cycle changes, relative humidity shocks, prolonged wet periods, prolonged dry periods, wind, wind-driven rain, wind-driven particulates, tides, solar radiation), and biological colonization (for example, moss, lichens).

The Historic Centre of Rethymno is threatened by diverse environmental hazards. During winter, flooding may reach the core of the historic center and cause serious damages to the historic structures. The physical effects of wind-driven rain and salt result in the erosion of the soft calcareous stones in the masonry of the Fortezza's fortifications, for instance. The stone erosion is further amplified by the moisture's evaporation cycle within the stone pores. The combination of wind, salt, and external maritime environmental conditions severely affect the mortar joints of the fortress walls and the plaster of the buildings. Their cracking and crumbling causes surface and masonry loss and, consequently, the inner structure of the buildings is further exposed to decay. The drying-wetting cycles, condensation and salt crystallization cycles cause mechanical damages in stones and metallic elements and favor chemical reactions within the stone and metals. Rainwater erodes the stone surface and causes plant growth and biodecay on the surface of the masonry. Furthermore, the rocky slopes of the hill, on which the fortress was built, are prone to the maritime winds. These examples provide a preliminary understanding of the natural hazard impacts that are needed in the hazard analysis matrix; however, a detailed vulnerability assessment needs to be conducted once hazards of interest are identified.

In addition to the tangible elements, intangible attributes linked to a site, either because they are still being practiced there, or because they otherwise rely on the site to be conveyed, might be affected by natural hazards and threats. Heritage sites may hold or support very diverse intangible elements, including social practices, rituals and festive events, knowledge and practices, and traditional craftsmanship (UNESCO World Heritage Centre 2017). The Fortezza Fortress has been one of the venues for the circa 28-year-old Rethymno Renaissance Festival, which includes theatrical performances and concerts. Outside of the festival, cultural events are often hosted in the fortress. A detailed analysis of the effects of natural hazards on tangible and intangible heritage elements and the loss of heritage values, however, needs to be conducted in the exposure and vulnerability assessments, which are beyond the scope of this article.

\section{Hazard Analysis and Evaluation at Rethymno}

As outlined in the section of Methodology, climate analysis and projections as well as hazard modeling and mapping are conducted for the HCR pilot site to analyze the potential hazards that have been already identified.

\subsection{Climate Analysis and Projections}

The climate change signal was determined by comparing future climatic conditions (based on climate projections for 
the 30-year period 2036-2065) to recent climatic conditions (based on the 30-year period 1971-2000). As climate model forcing scenario the RCP8.5 (Representative Concentration Pathway) was selected, which describes a future in which greenhouse gas emissions continue to increase (Riahi et al. 2011). This scenario only describes one of many possible "climate futures," and the actual change in climate will depend on how greenhouse gas emissions, among other things, will develop. RCP8.5 is the highest emission scenario available, and was chosen to provide an upper bound for the risk assessment.

As knowledge of the local climate conditions for the pilot site region is needed, the resolution of available global climate model results is too coarse for the analysis. Therefore, two different types of downscaling were considered to obtain results specifically for the immediate study area. A statistical downscaling was performed (Benestad et al. 2008). Global model results provided by the CMIP5 initiative (Coupled Model Intercomparison Project Phase 5) were downscaled using the local monitoring station data for Heraklion obtained through ECAD to optimize the coarse global model results for the pilot site region. In addition, regional climate model results provided by the EURO-CORDEX (Coordinated Downscaling Experiment-European Domain) project (Jacob et al. 2013) were used.

The selected climate indices were then calculated based on the local observations, statistical downscaling results, and regional climate model data. Average (and where appropriate extreme) values were determined for the historical and future reference periods. Prior to further analysis, multi-model ensembles for the statistically downscaled results and regional climate models were created. An ensemble refers to the averaging of the results of several models, and provides an improved "best estimate" projection, as the mean of the ensemble can be expected to outperform individual ensemble members under the assumption that simulation errors in different models are independent (IPCC 2007).

In the next step, the analysis results were represented graphically and the different indices were checked for consistency. After this quality check, the results were summarized in tabular form for all relevant STORM indices. The concept of these tables is illustrated in Table 4, for the heat wave and intense rainfall hazards. In the left column, the indices assigned to the hazards are listed. In the second column, the 1971-2000 baseline based on observations as well as the historical climate model runs is shown. Note that for the climate model results, the ensemble average and spread (standard deviation) are determined after calculating the 30-year baseline for each model individually. In the next two columns, the change for the time period 2036-2065 with respect to the
1971-2000 baseline (derived from the historical run) is shown for the statistical downscaling and regional climate model results. Here, the change projected by the individual models was derived first, and based on this the ensemble mean and spread (standard deviation) were determined as reported here. In the "comments" column, remarkable features are listed and an estimate of the projected climate change signal is given. Finally, these projected changes are summarized in a qualitative fashion to aid the integration in the consecutive risk assessment steps. This qualitative classification consists of five levels, and ranges from very low (indicated by a green color coding), low, medium, high, to very high (red). The assessment is performed for all indices separately, and an example of the assignment of the projected signals to the classification of change is shown for the heat wave indices in Table 5. It should be noted that this classification is solely based on climatological considerations. The level of risk will further be influenced by the exposure and vulnerability of the individual heritage cases to the hazard in the next steps of the risk assessment to determine the final risk level.

\subsection{Hazard Modeling and Mapping}

The hazard (GIS) modeling and mapping process of a series of natural hazards that were identified as the potential threats to the HCR pilot site area is provided in this section.

\subsubsection{Earthquake Hazard}

Earthquakes constitute one of the natural hazards worldwide that cause extremely severe damages to cultural heritage sites, especially in seismically active regions, such as the southeast Mediterranean basin (Papazachos and Comninakis 1978; Shaw et al. 2008). In order to assess earthquake hazards, several factors associated with earthquake events need to be acknowledged such as earthquake epicenters, proximity to active faults, and the type of geological formations (Sarris et al. 2010). This study considers events for shallow depth $(<70 \mathrm{~km})$ earthquakes around Rethymno City (within a buffer zone of $100 \mathrm{~km}$ ) for the period 1900-2006. There were 1167 earthquakes considered in total and the calculation of their density map (Mw magnitude) was generated. Moreover, the fact that the seismic intensity decreases (attenuates) with distance to faults, a cost distance parameter from the pilot site to the recorded faults was acknowledged (Cooke 1997). The geological formations were also considered as another parameter in this hazard map development process, since deep, weak soils tend to amplify and prolong the seismic waves shaking more than the stronger rock bed (Argyriou et al. 2016). All the datasets were implemented into a GIS 
Table 4 Climate analysis summary, illustrated for the heat wave and intense rainfall hazards for the study area in Crete, Greece

\begin{tabular}{|c|c|c|c|c|c|}
\hline \multirow[t]{2}{*}{ Index } & $\begin{array}{l}\text { Observations/histo } \\
\text { rical run }\end{array}$ & $\begin{array}{c}\text { Statistical } \\
\text { downscaling }\end{array}$ & $\begin{array}{l}\text { Regional climate } \\
\text { model }\end{array}$ & \multirow[b]{2}{*}{ Comments } & \\
\hline & $\begin{array}{l}\text { 1971-2000 } \\
\text { baseline }\end{array}$ & $\begin{array}{l}\text { Change } \\
\text { 2036-2065 } \\
\text { relative to } \\
1971-2000\end{array}$ & $\begin{array}{c}\text { Change } 2036-2065 \\
\text { relative to } \\
1971-2000\end{array}$ & & $\begin{array}{l}\text { Qualitative } \\
\text { classification } \\
\text { of change }\end{array}$ \\
\hline \multicolumn{6}{|l|}{ Heat waves } \\
\hline \multirow[t]{3}{*}{ Summer days } & 124.0 day/year & & & \multirow{3}{*}{$\begin{array}{l}\text { Large underestimate in } \\
\text { RCMs } \\
+20 \%-50 \%\end{array}$} & \\
\hline & $\begin{array}{l}128.3 \pm 0.1 \\
\text { day/year }\end{array}$ & $\begin{array}{l}+27.8 \pm 4.6 \\
\text { day/year }\end{array}$ & & & \\
\hline & $\begin{array}{l}68.4 \pm 21.9 \\
\text { day/year }\end{array}$ & & $\begin{array}{l}+35.1 \pm 6.0 \\
\text { day/year }\end{array}$ & & \\
\hline \multirow[t]{3}{*}{$\begin{array}{l}\text { Consecutive } \\
\text { summer days }\end{array}$} & $\begin{array}{l}73.0 \text { day/year }{ }^{\mathrm{a}} \\
131 \text { day/30-year }\end{array}$ & & & \multirow[t]{2}{*}{$\begin{array}{l}\text { Large underestimate in } \\
\text { RCMs }\end{array}$} & \\
\hline & $\mathrm{n} / \mathrm{a}^{*}$ & & & & \\
\hline & $\begin{array}{l}28.6 \pm 14.4 \\
\text { day/year } \\
56.6 \pm 22.4 \\
\text { day/30-year }\end{array}$ & & $\begin{array}{l}+33.7 \pm 14.3 \\
\text { day/year } \\
+39.6 \pm 10.5 \\
\text { day/30-year }\end{array}$ & $\begin{array}{l}+120 \% \\
\text { Extreme values: }+70 \%\end{array}$ & \\
\hline \multicolumn{6}{|c|}{ Intense rainfall } \\
\hline \multirow{3}{*}{$\begin{array}{l}\text { Heavy } \\
\text { precipitation } \\
\text { days }\end{array}$} & 14.5 day/year & & & \multirow[t]{2}{*}{ Slight wet bias in RCMs. } & \\
\hline & $\begin{array}{l}14.4 \pm 0.3 \\
\text { day/year }\end{array}$ & $\begin{array}{l}0.0 \pm 1.4 \\
\text { day/year }\end{array}$ & & & \\
\hline & $\begin{array}{l}15.3 \pm 5.0 \\
\text { day/year }\end{array}$ & & $-2.1 \pm 1.4$ day/year & Possibly minor decrease & \\
\hline \multirow{3}{*}{$\begin{array}{l}\text { Maximum 1- } \\
\text { day } \\
\text { precipitation } \\
\text { amount }\end{array}$} & $\begin{array}{l}50.3 \mathrm{~mm} / \text { day/year } \\
88.4 \mathrm{~mm} / \text { day/30- } \\
\text { year }\end{array}$ & & & \multirow[t]{3}{*}{$\begin{array}{l}\text { Underestimation of mean } \\
\text { values and overestimation } \\
\text { of extremes in RCMs }\end{array}$} & \\
\hline & $\mathrm{n} / \mathrm{a}^{*}$ & & & & \\
\hline & $\begin{array}{l}41.3 \pm 8.0 \\
\mathrm{~mm} / \text { day/year } \\
111.5 \pm 60.0 \\
\mathrm{~mm} / \text { day/30-yearr }\end{array}$ & & $\begin{array}{l}+1.0 \pm 4.2 \\
\mathrm{~mm} / \text { day/year } \\
-12.5 \pm 57.4 \\
\mathrm{~mm} / \text { day/30-yearr }\end{array}$ & & \\
\hline
\end{tabular}

RCM stands for "regional climate model." Summer days: number of days with maximum temperatures over $25^{\circ} \mathrm{C}$; consecutive summer days: maximum consecutive days during which maximum temperatures were over $25{ }^{\circ} \mathrm{C}$ ( $\left(30\right.$-year average of yearly maxima, ${ }^{\mathrm{b}} 30$-year maximum); heavy precipitation days: days with at least $10 \mathrm{~mm}$ of precipitation; maximum 1-day precipitation amount: maximum amount of precipitation occurring in a 1-day interval ( ${ }^{\mathrm{a}} 30$-year average of yearly maxima, ${ }^{\mathrm{b}} 30$-year maximum). Note that due to the nature of the statistical downscaling technique, no meaningful results for consecutive summer days and maximum 1-day precipitation amounts can be derived

environment following appropriate standardization, rating, and ranking of the datasets (Argyriou et al. 2016). The reason is that in order to combine them in a single analysis, each cell for each factor needed to be reclassified into a common hazard assessment scale such as 1 to 10 , with 10 being a location with the highest likelihood or severity of the hazard occurrence. A weighted overlay procedure with an equal weighting for the sum of the diverse three parameters was performed in order to derive the final earthquake hazard map (Fig. 5).

\subsubsection{Landslide Hazard}

Due to the geomorphology of the terrain, landslides have been considered as a hazard causing damages to cultural heritage assets (Agapiou et al. 2015). The occurrence of landslides can be a result of human interventions in the landscape and/or due to geomorphological and
Table 5 Classification of the quantitative scale for the heat wave indices shown in Table 4

\begin{tabular}{|c|c|c|c|}
\hline $\begin{array}{l}\text { Hazards and } \\
\text { threats }\end{array}$ & Color scale & $\begin{array}{c}\text { Qualitative } \\
\text { scale }\end{array}$ & $\begin{array}{c}\text { Quantitative } \\
\text { scale }\end{array}$ \\
\hline \multicolumn{4}{|l|}{ Heat waves } \\
\hline \multirow[t]{6}{*}{ Summer days } & & & Increase in days \\
\hline & & Very high & 40 or more \\
\hline & & High & 30 to below 40 \\
\hline & & Medium & 20 to below 30 \\
\hline & & Low & 10 to below 20 \\
\hline & & Very low & Below 10 \\
\hline \multirow{6}{*}{$\begin{array}{l}\text { Consecutive } \\
\text { summer days }\end{array}$} & & & Increase in $\%$ \\
\hline & & Very high & 50 or more \\
\hline & & High & 30 to below 50 \\
\hline & & Medium & 15 to below 30 \\
\hline & & Low & 5 to below 15 \\
\hline & & Very low & Below 5 \\
\hline
\end{tabular}



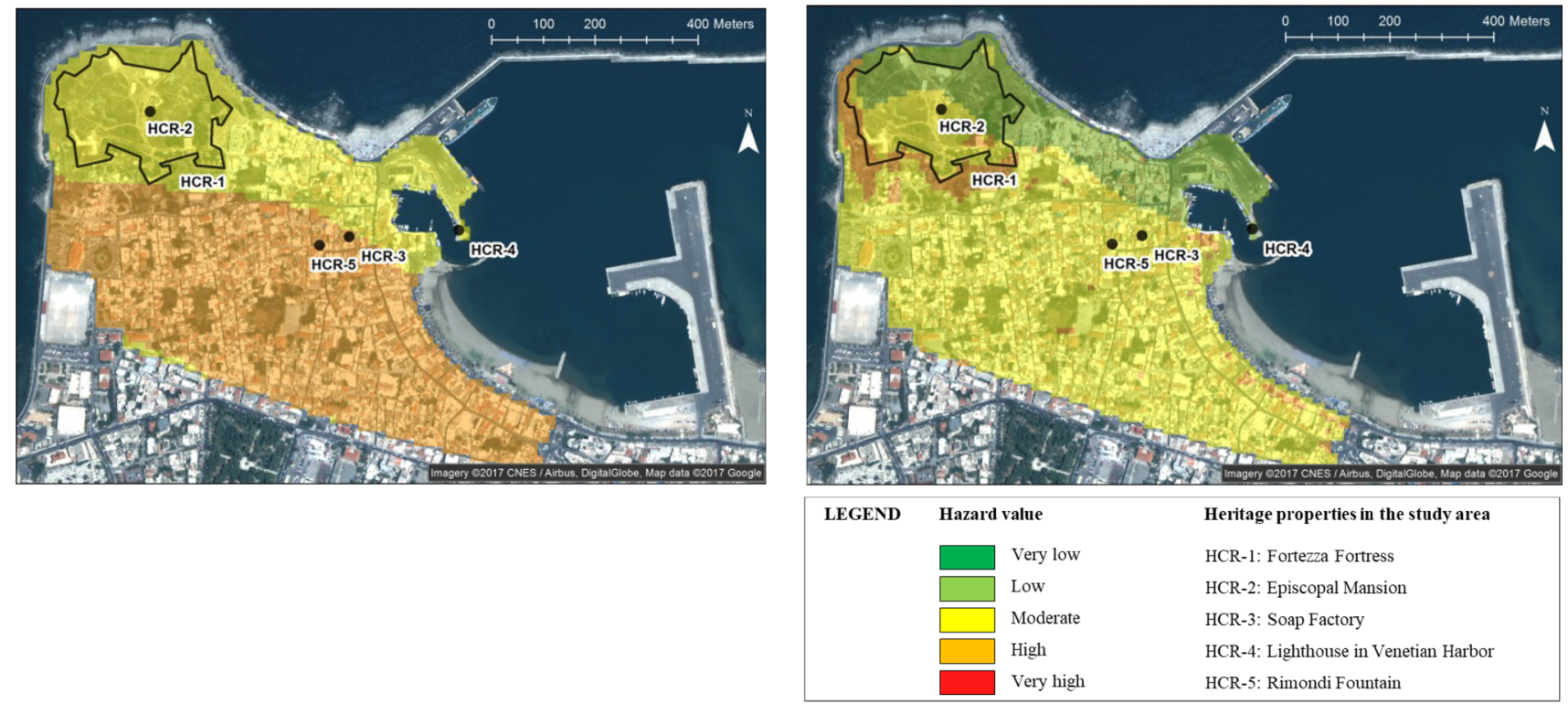

Fig. 5 Left: Earthquake hazard map for the site area in Rethymno, Crete, Greece representing corresponding ground susceptibility; Right: Landslide hazard map for the site area representing corresponding ground susceptibility

climatological factors. In order to calculate the landslide hazard map, various factors were considered such as hydrolithology, geomorphometry (slope gradient), and climatic attributes (a complete time series of rainfall data of the 1990-2000 period) (Alexakis and Sarris 2010; Kouli et al. 2010). The spatial distribution of the mean rainfall for each month of the year was derived by applying the inverse distance weighting (IDW) interpolation method, as collected from various allocated meteorological stations and provided by the Hellenic National Meteorological Service (HNMS). The overall sum of these spatially distributed months provided the mean annual rainfall distribution. The hydrolithological formations (IGME 1971) were categorized in relation to the mean annual rainfall datasets, with higher values capable of triggering landslide events in relation to lower values (Alexakis and Sarris 2010). Similarly, the slope gradient was derived, via the TanDEM-X elevation model, and then categorized in relation to the mean annual rainfall datasets. All these factors were imported as spatial layers into a GIS environment and their range of values was reclassified with various ratings according to their association and linkage to possible landslide phenomena. The final landslide hazard map was based on the combination of the various ranked datasets through the application of a simplified weighted-factors model to provide an outcome advantageous to regions exposed to potential landslide phenomena (Fig. 5).

\subsubsection{Wind Hazard}

Because the Historic Centre of Rethymno (HCR) is located on the northern coast of the island of Crete, exposure to the strong north winds may cause serious damages to the historic structures. The wind hazard map was developed considering geomorphological characteristics such as aspect, with respect to the dominant strong north wind direction as recorded by the available climatological data information (HNMS 2017). The north-facing facades of the historical monuments in the HCR are exposed to the dominant north wind. There were five classes derived according to the facing aspect categories: (1) very high for north facing; (2) high for northwest and northeast facing; (3) moderate for east and west facing; (4) low for southeast and southwest facing; and (5) very low for south facing.

\subsubsection{Flash and Coastal Flooding Hazard}

With respect to rainfall-induced flooding in the HCR, it occurs only in the case of intense and abrupt rainfall, lasting only a few hours at maximum. Coastal flooding (for example, storm surge) seems to be a significant threat to the historical buildings and monuments of the town of Rethymno, especially for those structures that are facing towards the north, as is the case for the Lighthouse in the Venetian harbor. The flash flooding hazard map was developed considering as an input dataset the TanDEM-X elevation model, while the spatial modeling process was conducted with various spatial analysis algorithms such as 

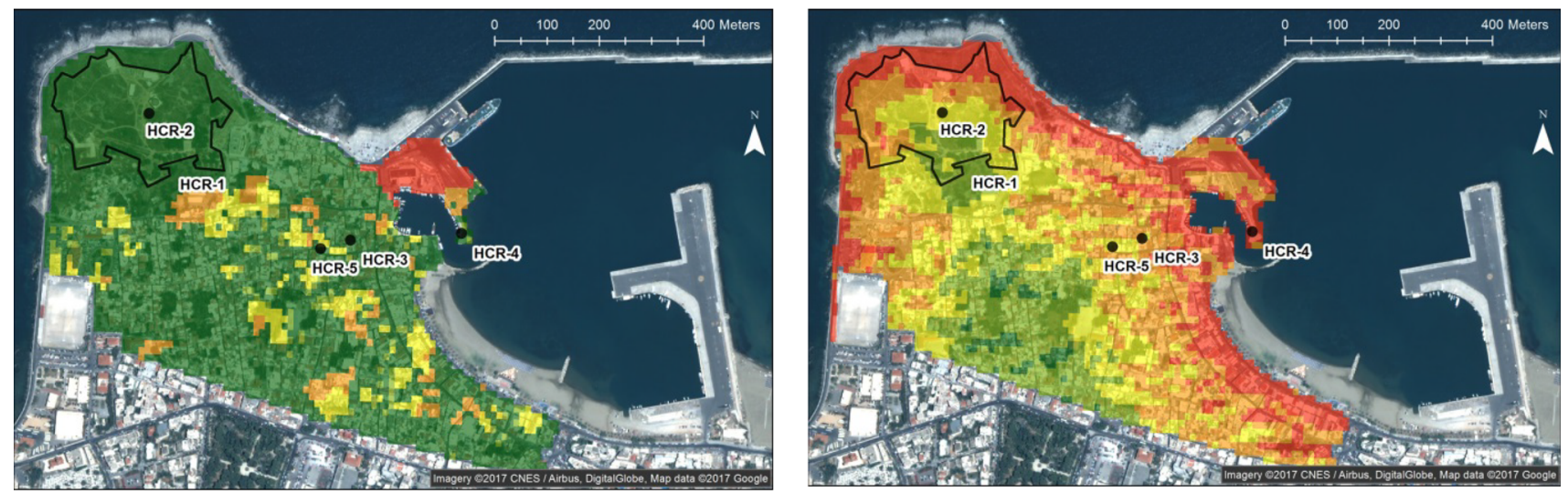

\begin{tabular}{|lll|}
\hline LEGEND & \multicolumn{1}{l|}{ Hazard value } & Heritage properties in the study area \\
& Very low & HCR-1: Fortezza Fortress \\
\hline & Low & HCR-2: Episcopal Mansion \\
\hline & Moderate & HCR-3: Soap Factory \\
\hline & High & HCR-4: Lighthouse in Venetian Harbor \\
\hline & Very high & HCR-5: Rimondi Fountain \\
\hline
\end{tabular}

Fig. 6 Left: Flash flooding hazard map for the site area in Rethymno, Crete, Greece representing likelihood of flooding areas; Right: Salinization hazard map for the site area representing corresponding ground susceptibility

flow accumulation, flow direction, cost allocation, and cost distance (Fig. 6). Based on the combination of the derived information, through the various spatial analysis algorithms, the least accumulative cost distance and its least cost source were determined to define the flood-prone areas at the HCR. The zones that resulted were the ones more exposed to potential flash flood events for the HCR site (Fig. 6). Similarly, the coastal flooding hazard map was derived highlighting the zones exposed to high waves or tsunamis. This was achieved by acknowledging the distance to the coastline ( $20 \mathrm{~m}$ inundation) with respect to elevation (up to $3 \mathrm{~m}$ ) within a weighted overlay model.

\subsubsection{Salinization Hazard}

Salinization is a slow-onset threat, in particular for monuments located close to the coastline (Robinson et al. 2010; Agapiou et al. 2015). In the case of the HCR, the north section of the Fortezza castle and the Egyptian Lighthouse in the Venetian harbor are the most exposed to the sea. A salinization hazard map can be developed by acknowledging both the distance to the coastline with respect to elevation and the derived aspect related to the dominant recorded wind direction. Specifically, the derived geomorphological information (elevation and aspect) can ensure the determination of the areas exposed to higher degrees of salinization, that is, more prone to salt-induced decay, with regard to their lower elevation and their facing aspect (northwards) regarding the dominant wind direction (north). The spatial datasets were then implemented within the GIS environment, and by using a weighted overlay procedure for all datasets, the areas with the higher susceptibility to salinization were derived. There were five classes produced to categorize the salinization susceptibility in relation to distance from the coastline (Fig. 6).

\subsection{Hazard Analysis and Evaluation}

As described in the Methodology section, a semiquantitative method was applied to incorporate the ranking factors of likelihood, severity, relevance of hazards to the sites, and expected intensity of impacts into the hazard analysis procedure. Accordingly, two main factors of "event parameter" and "expected intensity of impact" were derived to be incorporated into a hazard analysis matrix (Table 6). The criterion of "event parameters" was calculated by summing up hazard likelihood, severity, and relevance to the site. Then it was reclassified in order to allow its integration into the hazard matrix. Applying the equal interval method, the event parameter scores were reclassified to divide the range of values into five equalsized classes of very low $(<5.4)$, Low (5.4-7.8), Medium (7.8-10.2), High (10.2-12.6), and Very high (>12.6) (Table 6). The factor of "expected intensity of impact" is a rapid estimation of impact, according to the existing data and expert opinions to facilitate the identification of significant hazards. In the further steps of risk assessment, however, a detailed analysis of potential impacts needs to be carried out while applying exposure and vulnerability analysis methods.

According to the ranking factors, the identified hazards and threats may fall into one of the five zones of Very low 
Table 6 Hazard analysis matrix for the site area in Rethymno, Crete, Greece, based on the semiquantitative analysis of the ranking factors

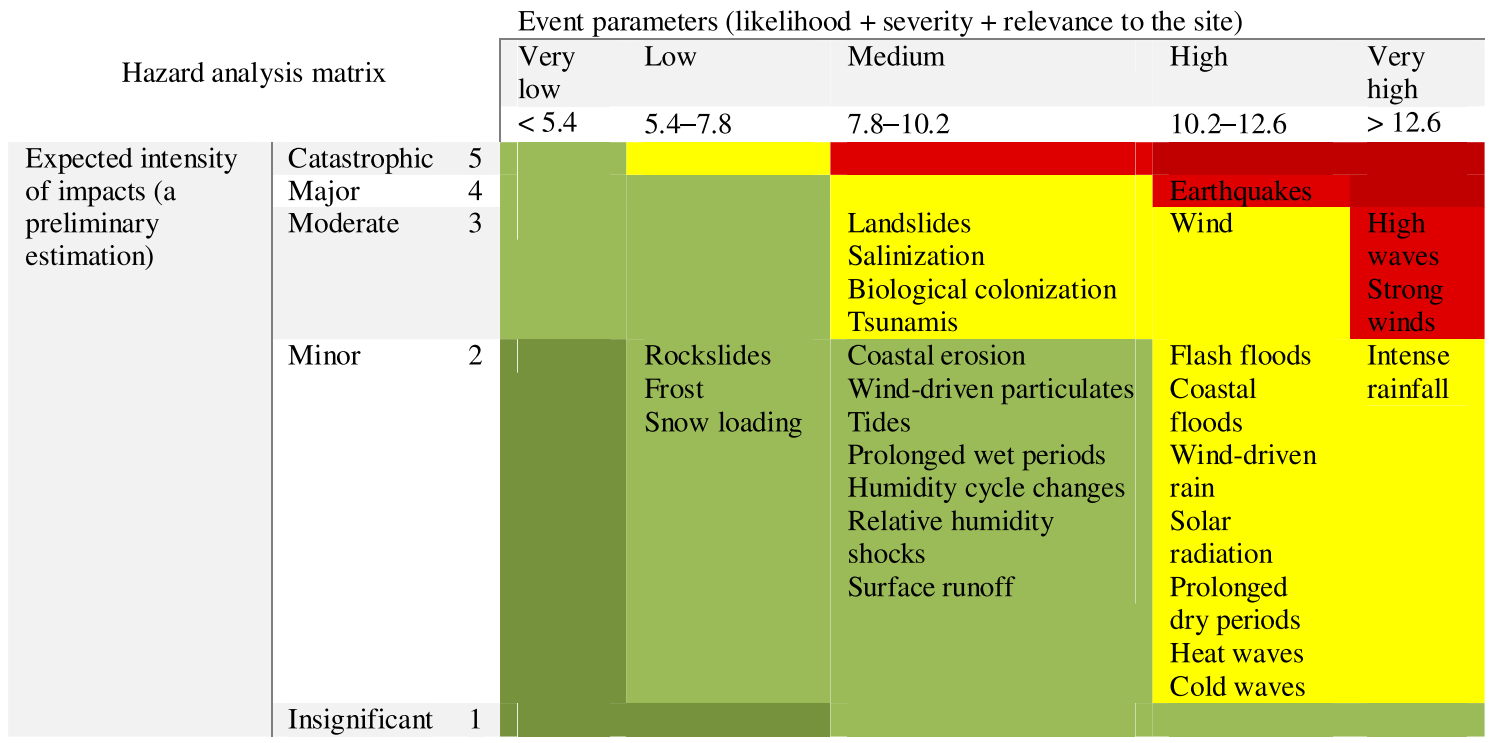

(dark green), Low (light green), Medium (yellow), High (orange), and Very high (red) (Table 6). The qualitative interpretation of the hazards in the hazard analysis matrix shares a better understanding of the situation in a multihazard context with the site managers and stakeholders engaged in the safeguarding of the heritage site. Subsequently, a hazard evaluation needs to be conducted based on the above hazard matrix in order to determine those hazards that need to be incorporated into the next steps of the risk assessment procedure. The ALARP (As Low As Reasonably Practicable) principle (adapted from AEMC 2010) was applied to prioritize the hazards and threats for the further steps of ongoing risk assessment.

Figure 7 shows how the results of the hazard assessment contribute to the risk assessment procedure. According to the proposed procedure (Fig. 7) and the results of the hazard analysis matrix for the HCR (Table 6), those hazards with a High or Very high significance (for example, earthquakes and strong winds) fall into the red zone and those with a Medium significance (for example, coastal floods and heat waves) fall into the yellow zone. Within the overall framework, it means that both zones need to be incorporated into the further steps of risk assessment, in particular vulnerability assessment, to adequately analyze the structural sensitivity of the heritage assets to the corresponding hazards. Hazards in the green zone (for example, surface runoff) are not necessarily subject to the further risk assessment procedure; however, they should be considered within the heritage conservation system through the regular monitoring of the structural elements and climate parameters, for instance.
In the further steps of the risk assessment procedure, risks need to be identified and analyzed according to the elements of risk defined in the methodologies, depending on the objectives of risk management for a heritage site. For instance, in the exposure assessment, the value of movable and immovable heritage assets and their associated intangible elements can be analyzed. Vulnerability assessment may focus on the structural susceptibility of the heritage elements to the hazards of interest as well as on the nonstructural factors that influence the adaptive and coping capacity of the institutional, conservation, and management system. The results of the risk assessment will provide risk reduction strategies with tolerable and intolerable risks that need risk treatment options. The linkage between the risk management, whether at the individual site or overall urban level, and the heritage management system is essential to ensure the efficiency and effectiveness of the planning and implementation of strategies.

Apart from the overall significance of the hazards at the site level, the GIS hazard maps allow for a common understanding of the hazards at the single monument level. The Fortezza Fortress (HCR-1), for example, is exposed to earthquake and landslides (Fig. 4), and its fortification walls in the northern part are exposed to salinization (Fig. 5). A detailed exposure and vulnerability assessment needs to be conducted for the case of the Fortezza Fortress to address the potential impacts of the corresponding hazards. This is the case for the Lighthouse in the Venetian harbor (HCR-4) regarding salinization, and for the Soap Factory (HCR-3) and the Rimondi Fountain (HCR-5) regarding earthquakes. In general, the larger the structural detail that is mapped within the GIS, the better resolution 


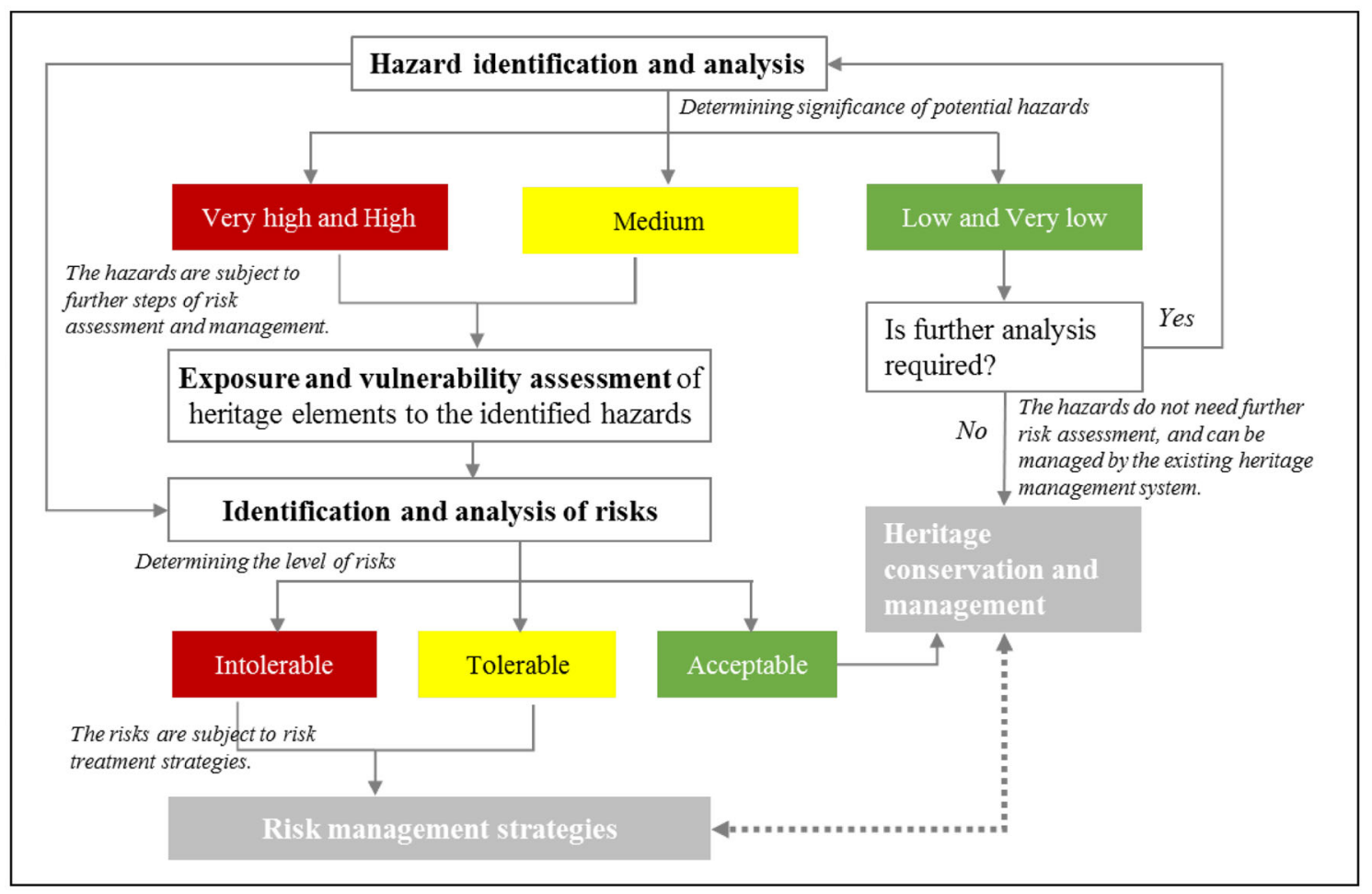

Fig. 7 Natural hazard evaluation and integration into the ongoing risk assessment and management of cultural heritage

of the definition of the specific hazards is achieved. The same holds true with respect to the input information that defines the hazards themselves, either coming from a dense network of close-by sensors or other measurements and analyses. Looking at the climate projections (Table 4), there are some slow-onset hazards (for example, heat waves) that have not been considered as serious threats, but are expected to increase dramatically over the next 50 years. In this case, even though there might not be any past damages or deterioration patterns due to such hazards, their potential impacts on historic structures need to be addressed within the risk assessment and management procedure.

\section{Conclusion}

To frame risk assessment and management for heritage sites exposed to a wide range of hazards, there is a vital need to determine the scope of past and future hazards and threats. This study proposes a classification of natural hazards (sudden- and slow-onset) while taking into account future alterations due to climate change. The final classification list is comprehensive enough to be applicable to diverse types of heritage sites in different environmental contexts. This comprehensiveness, supported by the distinction between sudden- and slow-onset hazards, was a key in the identification and perceived significance of the hazards affecting the Historic Centre of Rethymno.

All potential hazards and threats should be considered in the conservation of heritage properties, but not necessarily be subject to a rigorous (structural) vulnerability and risk assessment procedure, which can be extremely time- and resource-consuming for large cultural sites. There is a need to analyze and prioritize the hazards to determine those that need to be incorporated into the further procedure of risk assessment and management. One of the critical challenges to achieving this objective was the integration of historical data (for example, meteorological records and geological features), future climate projections, and the site manager's opinions because all of these parameters constitute essential data in the hazard assessment procedure. The proposed methodology tackles this need by conducting a multi-criteria analysis followed by a hazard analysis matrix as well as the development of the hazard evaluation and integration into the ongoing risk assessment and management of cultural heritage.

Overall, the proposed procedure integrates GIS spatial modeling, hazard mappings, and climate model projections into a multi-criteria assessment method to provide the study area with a multiple hazard context subject to further steps of risk assessment. The results of the procedure will further contribute to the vulnerability and risk assessment with the information about the nature and severity of the potential significant hazards, and will provide risk 
mitigation strategies with options for avoiding the sources of risk or reducing their likelihood and severity. Further research is needed to link multi-hazard analysis and vulnerability assessment in the context of historic sites and cities while incorporating both tangible and intangible heritage attributes into the risk assessment procedure.

Acknowledgements This article is based on the STORM (Safeguarding Cultural Heritage through Technical and Organisational Resources Management) Project, funded by the European Union's Horizon 2020 research and innovation program under Grant agreement No. 700191. The article reflects only the authors' views, and the European Union is not liable for any use that may be made of the information contained herein. We would like to thank the STORM consortium, in particular, the Ephorate of Antiquities of Rethymno (EFARETH), for supporting the consultation and communication in the risk assessment process.

Open Access This article is distributed under the terms of the Creative Commons Attribution 4.0 International License (http://crea tivecommons.org/licenses/by/4.0/), which permits unrestricted use, distribution, and reproduction in any medium, provided you give appropriate credit to the original author(s) and the source, provide a link to the Creative Commons license, and indicate if changes were made.

\section{References}

AEMC (Australian Emergency Management Committee). 2010. National Emergency Risk Assessment Guidelines (NERAG). Hobart: Tasmanian State Emergency Service. http://www. preventionweb.net/publications/view/41033. Accessed 8 Feb 2017.

AEMC (Australian Emergency Management Committee). 2015. National Emergency Risk Assessment Guidelines: Practice guide, commonwealth of Australia 2015. https://knowledge. aidr.org.au/media/1061/practice-guide-10-1-national-emer gency-risk-assessment-guidelines.pdf. Accessed 8 Feb 2019.

Agapiou, A., V. Lysandrou, D.D. Alexakis, K. Themistocleous, B. Cuca, A. Argyriou, A. Sarris, and D.G. Hadjimitsis. 2015. Cultural heritage management and monitoring using remote sensing data and GIS: The case study of Paphos area, Cyprus. Computers, Environment and Urban Systems 54: 230-239.

Alexakis, D., and A. Sarris. 2010. Environmental and human risk assessment of the prehistoric and historic archaeological sites of western Crete (Greece) with the use of GIS, remote sensing, fuzzy logic and neural networks. In Lecture notes in computer science No. 6436: Digital heritage-Remote sensing for archaeology and cultural heritage management and monitoring, ed. M. Ioannides, D. Fellner, A. Georgopoulos, and D.G. Hadjimitsis, 332-342. Third International Conference, EuroMed 2010, Lemessos, Cyprus, 8-13 November 2010, Proceedings. Berlin: Springer.

Ammann, W.J. 2006. Risk concept, integral risk management and risk governance. In RISK21-Coping with risks due to natural hazards in the 21st century, ed. W.J. Ammann, S. Dannenmann, and L. Vulliet, 3-23. London: Taylor \& Francis Group.

Argyriou, A.V., R.M. Teeuw, D. Rust, and A. Sarris. 2016. GIS multicriteria decision analysis for assessment and mapping of nontectonic landscape deformation: A case study from Crete. Geomorphology 253: 262-274.
Below, R., A. Wirtz, and D. Guha-Sapir. 2009. Disaster category classification and peril terminology for operational purposes. Brussels, Munich: Centre for Research on the Epidemiology of Disasters (CRED) and Munich Reinsurance Company (Munich $\mathrm{RE})$.

Benestad, R.E., I. Hanssen-Bauer, and D. Chen. 2008. Empiricalstatistical downscaling. Singapore: World Scientific Publishing.

Birkmann, J. 2006. Measuring vulnerability to promote disasterresilient societies: Conceptual frameworks and definitions. In Measuring vulnerability to natural hazards: Towards disaster resilient societies, ed. J. Birkmann, 9-54. Tokyo: United Nations University Press.

Bokwa, A. 2013. Natural hazard. In Encyclopedia of natural hazards, ed. P.T. Bobrowsky, 711-718. Dordrecht: Springer.

Camuffo, D. 1997. Perspectives on risks to architectural heritage. In Saving our architectural heritage-The conservation of historic stone structures. Report of the Dahlem Workshop on Saving our Architectural Heritage-Conservation of Historic Stone Structures, Berlin, March 3-8, 1996, ed. N.S. Baer and R. Snethlage, 63-88. New York: Wiley.

Colette, A. (ed.). 2007. Climate change and world heritage: Report on predicting and managing the impacts of climate change on world heritage and strategy to assist states parties to implement appropriate management responses. Paris: UNESCO World Heritage Centre. https://unesdoc.unesco.org/images/0016/ 001600/160019m.pdf. Accessed 15 Oct 2016.

Cooke, M. 1997. Fracture localization along faults with spatially varying friction. Journal of Geophysical Research 102(B10): 22425-22434.

D’Ayala, D.F., A. Carriero, F. Sabbadini, D. Fanciullacci, P. Ozelik, M. Akdogan, and Y. Kaya. 2008. Seismic vulnerability and risk assessment of cultural heritage buildings in Istanbul, Turkey. In Proceedings of the 14th World Conference on Earthquake Engineering, 12-17 October 2008, Beijing, China. http://www. iitk.ac.in/nicee/wcee/article/14_S11-079.PDF. Accessed 15 Oct 2015.

Daly, C. 2011. Climate change and the conservation of archaeological sites: A review of impacts theory. Conservation and Management of Archaeological Sites 13(4): 293-310.

Dimakopoulos, I. 1970. Megali Vryssi, a Venetian fountain of

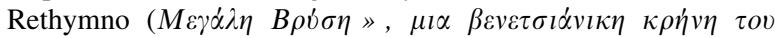

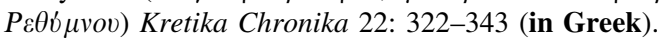

Drdácký, M., and M. Chapuis (eds.). 2007. Safeguarded cultural heritage: Understanding \& viability for the enlarged Europe. In Proceedings of the 7th European conference "Sauveur", 31 May-3 June 2006, Prague, Czech Republic, vol. 2. Prague: Institute of Theoretical and Applied Mechanics of the Czech Academy of Sciences.

FEMA (Federal Emergency Management Agency). 2004. Using HAZUS-MH for risk assessment: How-to-guide. Washington, DC: Federal Emergency Management Agency. http://mitigation clearinghouse.nibs.org/content/fema-433-using-hazus-mh-riskassessment-how-\%C2\%A0guide-2004. Accessed 8 Mar 2017.

FEMA (Federal Emergency Management Agency). 2005. Integrating historic property and cultural resource considerations into hazard mitigation planning: How-to guide (FEMA 386-6). Washington, DC: Federal Emergency Management Agency. http://wyohomelandsecurity.state.wy.us/grants/hmpg/Integrat ing_Historic_Property_Cultural_Resource_Considerations_into_ hmplanning.pdf. Accessed 20 Oct 2016.

FEMA (Federal Emergency Management Agency). 2012. Threat and hazard identification and risk assessment. Washington, DC: Federal Emergency Management Agency. https://www.fema. gov/media-library-data/.../CPG201_htirag_2nd_edition.pdf. Accessed 20 Nov 2016. 
Füssel, H.-M. 2012. Climate change, impacts and vulnerability in Europe 2012: An indicator-based report. Kopenhagen: European Environment Agency. https://www.haw-hamburg.de/.../user.../ Dr.Jol.EEA_3Sep_WSCCA_2015.pdf. Accessed 22 Dec 2016.

Gaillard, J.C., and I. Kelman. 2013. Disaster research and policy, history. In Encyclopedia of natural hazards, ed. P.T. Bobrowsky, 160-164. Dordrecht: Springer.

Glade, T., and D. Alexander. 2013. Classification of natural disasters. In Encyclopedia of natural hazards, ed. P.T. Bobrowsky, 78-82. Dordrecht: Springer.

HNMS (Hellenic National Meteorological Service). 2017. Climatic data for selected stations in Greece. Climatic bulletins from 2009-2017.

IGME (Institute of Geology and Mineral Exploration). 1971. Geological map of Greece, western Crete sheets. Scale: 1:50,000. Athens: Institute of Geology and Mineral Exploration.

IPCC (Intergovernmental Panel on Climate Change). 2007. Climate change 2007: The physical science basis. Contribution of Working Group I to the Fourth Assessment Report of the Intergovernmental Panel on Climate Change, ed. S. Solomon, D. Qin, M. Manning, Z. Chen, M. Marquis, K.B. Averyt, M. Tignor, and H.L. Miller. Cambridge and New York: Cambridge University Press.

IPCC (Intergovernmental Panel on Climate Change). 2012. Glossary of terms. In Managing the risks of extreme events and disasters to advance climate change adaptation, ed. C.B. Field, V. Barros, T.F. Stocker, D. Qin, D.J. Dokken, K.L. Ebi, M.D. Mastrandrea, K.J. Mach, et al., 555-564. A special report of Working Groups I and II of the Intergovernmental Panel on Climate Change. Cambridge and New York: Cambridge University Press.

ISO (International Organization for Standardization). 2009. ISO 31000. Risk management: Principles and guidelines. Sydney: Standards Australia International.

Jacob, D., J. Petersen, B. Eggert, A. Alias, O.B. Christensen, L.M. Bouwer, A. Braun, A. Colette, et al. 2013. EURO-CORDEX: New high-resolution climate change projections for European impact research. Regional Environmental Change 14(2): 1-16.

Kelman, I. 2018. Lost for words amongst disaster risk science vocabulary? International Journal of Disaster Risk Science 9(3): 281-291.

Klok, E.J., and A.M.G. Klein Tank. 2009. Updated and extended European dataset of daily climate observations. International Journal of Climatology 29(8): 1182-1191.

Kouli, M., C. Loupasakis, P. Soupios, and F. Vallianatos. 2010. Landslide hazard zonation in high risk areas of Rethymno Prefecture, Crete Island, Greece. Natural Hazards 52(3): 599-621.

Menoni, S., and A. Pugliano. 2013. Civil protection and crisis management. In Encyclopedia of natural hazards, ed. P.T. Bobrowsky, 69-78. Dordrecht: Springer.

Nara +20 . 2016. On heritage practices, cultural values, and the concept of authenticity. Heritage \& Society 8(2): 144-147.

Papadakis, C. 2009. The Egyptian lighthouse of Rethymno ( $O$

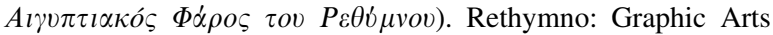
Karagiannakis (in Greek).

Papazachos, B.C., and P.E. Comninakis. 1978. Deep structure and tectonics of the Eastern Mediterranean. Tectonophysics 33: 285-296.

Paraskevas, P. 2003. The soap factories of Rethymno $\left(\mathrm{O}_{l}\right.$

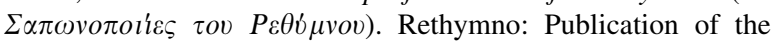
Experimental High School of Rethymno (in Greek).

RESILENS (Realising European ReSILiencE for Critical INfraStructure). 2016. D2.2: Qualitative, semi-quantitative and quantitative methods and measures for resilience assessment and enhancement-Report and templates. The European Union's
Horizon 2020 research and innovation programme. http:// resilens.eu/. Accessed 16 Jun 2017.

Revez, M.J., J. Delgado Rodrigues, N. Proença, J.M. Lobo de Carvalho, P. Coghi, M.C. Capua, U. Santamaria, S. Boi, and F. Perossini. 2016. Risk as a conceptual tool for an integrated management of change: The perspective of project STORM $(O$ risco como ferramenta conceptual de uma gestão integrada da mudança: a perspectiva do projecto STORM). In IberianAmerican Congress "Heritage: Its Materials and Its Immaterials" (Congresso Ibero-Americano Património, suas Matérias e Imatérias) (CD-ROM), ed. M. Menezes, J. Delgado Rodrigues, and D. Costa. Lisbon: LNEC (Laboratório Nacional de Engenharia Civil-National Laboratory for Civil Engineering) (in Portuguese).

Riahi, K., S. Rao, V. Krey, C. Cho, V. Chirkov, G. Fischer, G. Kindermann, N. Nakicenovic, P. Rafaj. 2011. RCP 8.5-A scenario of comparatively high greenhouse gas emissions. Climatic Change 109: Article 33.

Robinson, M.H., C.R. Alexander, C.W. Jackson, C.P. McCabe, and D. Crass. 2010. Threatened archaeological, historic, and cultural resources of the Georgia coast: Identification, prioritization and management using GIS technology. Geoarchaeology 25(3): 312-326.

Sabbioni, C., M. Cassar, P. Brimblecombe, and R.A. Lefevre. 2009. Vulnerability of cultural heritage to climate change. European and Mediterranean Major Hazards Agreement (EUR-OPA), 20 November 2008, Strasbourg. https://www.coe.int/t/dg4/.../ Ravello_APCAT2008_44_Sabbioni-Jan09_EN.pdf. Accessed 15 Dec 2016.

Sarris, A., S. Karakoudis, X. Bidaki, and P. Soupios. 2005. Study of the morphological attributes of Crete through the use of remote sensing techniques. IASME Transactions 2(6): 1043-1051.

Sarris, A., C. Loupasakis, P. Soupios, V. Trigkas, and F. Vallianatos. 2010. Earthquake vulnerability and seismic risk assessment of urban areas in high seismic regions: Application to Chania City, Crete Island, Greece. Natural Hazards 54(2): 395-412.

SEERISK (South East Europe Risk). 2014. General description of the common risk assessment methodology. In Guideline on climate change adaptation and risk assessment in the Danube macroregion, ed. M. Pavlović, and A. Horváth, 16-28. SEERISK Consortium. http://www.seeriskproject.eu/seerisk/. Accessed 8 Apr 2017.

Shaw, B., N.N. Ambraseys, P.C. England, M.A. Floyd, G.J. Gorman, T.F.G. Higham, J.A. Jackson, J.M. Nocquet, C.C. Pain, and M.D. Piggott. 2008. Eastern Mediterranean tectonics and tsunami hazard inferred from the AD 365 earthquake. Nature Geoscience 1(4): 268-276.

Sillmann, J., V.V. Kharin, F.W. Zwiers, X. Zhang, and D. Bronaugh. 2013. Climate extremes indices in the CMIP5 multimodel ensemble: Part 2. Future climate projections. Journal of Geophysical Research: Atmospheres 118(6): 2473-2493.

Simmons, D.C., R. Dauwe, R. Gowland, Z. Gyenes, A.G. King, D. Riedstra, and S. Schneiderbauer. 2017. Qualitative and quantitative approaches to risk assessment. In Science for disaster risk management 2017: Knowing better and losing less, ed. K. Poljanšek, M. Marín Ferrer, T. De Groeve, and I. Clark, 42-56. Luxembourg: European Commission.

Smith, K., and D.N. Petley. 2009. Environmental hazards: Assessing risk and reducing disaster. London: Routledge.

Steriotou, I. 1992. The Venetian Fortifications of Rethymno (1540-

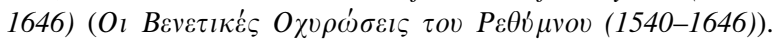
Two vols. Athens: Archaeological Receipts Fund (in Greek).

Stewart, I. 2013. Disasters. In Encyclopedia of natural hazards, ed. P.T. Bobrowsky, 175-187. Dordrecht: Springer.

Stillwell, H.D. 1992. Natural hazards and disasters in Latin America. Natural Hazards 6(2): 131-159. 
STORM (Safeguarding Cultural Heritage through Technical and Organisational Resources Management). 2016-2019. The European Union's Horizon 2020 research and innovation programme. http://www.storm-project.eu/. Accessed 16 Aug 2018.

UN (United Nations). 2015. Transforming our world: The 2030 agenda for sustainable development. https://sustainabledevelop ment.un.org/content/documents/21252030\%20Agenda $\% 20$ for $\%$ 20Sustainable\%20Development\%20web.pdf. Accessed 20 Oct 2016.

UNDP/UNDRO (United Nations Development Programme/United Nations Disaster Relief Organization). 1992. Disaster management training programme: An overview of disaster management. UNDP/UNDRO Disaster Management Training Programme.

UNESCO World Heritage Centre, ICCROM (International Centre for the Conservation and Restoration of Monuments), ICOMOS (International Council on Monuments and Sites), and IUCN (International Union for Conservation of Nature). 2010. Managing disaster risks for world heritage. Paris: World Heritage Resource Manual, UNESCO. http://whc.unesco.org/uploads/ activities/documents/activity-630-1.pdf. Accessed 20 Dec 2016.

UNESCO World Heritage Centre. 2014. State of conservation of world heritage properties: A statistical analysis (1979-2013). Paris: UNESCO World Heritage Centre.

UNESCO World Heritage Centre. 2015. Final report on the results of the second cycle of the periodic reporting exercise for the Europe region and action plan. Paris: UNESCO World Heritage
Centre. https://whc.unesco.org/en/eur-na/. Accessed 20 Nov 2016.

UNESCO World Heritage Centre. 2017. The operational guidelines for the implementatio20 of the world heritage convention. Paris: UNESCO World Heritage Centre. http://whc.unesco.org/en/ guidelines/. Accessed 20 Dec 2017.

UNFCCC (United Nations Framework Convention on Climate Change). 2012. Slow onset events: Technical paper. https:// unfccc.int/resource/docs/2012/tp/07.pdf. Accessed 20 Nov 2016.

UNISDR (United Nations International Strategy for Disaster Reduction). 2015a. Proposed updated terminology on disaster risk reduction: A technical review. The United Nations Office for Disaster Risk Reduction. https://www.preventionweb.net/files/ 45462_backgoundpaperonterminologyaugust20.pdf. Accessed 20 Nov 2016.

UNISDR (United Nations International Strategy for Disaster Reduction). 2015b. Sendai framework for disaster risk reduction 20152030. http://www.preventionweb.net/files/43291_sendaiframe workfordrren.pdf. Accessed 8 Jan 2017.

Wisner, B., P. Blaikie, T. Cannon, and I. Davis. 2004. At risk: Natural hazards, people's vulnerability, and disasters, 2nd edn. London: Routledge.

Zschau, J. 2017. Where are we with multihazards, multirisks assessment capacities? In Science for disaster risk management 2017: Knowing better and losing less, ed. K. Poljanšek, M. Marín Ferrer, T. De Groeve, and I. Clark, 96-128. Luxembourg: European Commission. 